$\$$ Research Square
Preprints are preliminary reports that have not undergone peer review.

They should not be considered conclusive, used to inform clinical practice, or referenced by the media as validated information.

\title{
Symptomatology of Coronavirus Disease 2019 (COVID-19) - Lessons from a meta-analysis across 13 countries
}

Champika Saman Kumara Gamakaranage ( $\sim$ champikasri@gmail.com )

Department of Clinical Medicine, Faculty of Medicine, University of Colombo, Sri Lanka https://orcid.org/0000-0001-6040-5649

Dineshani Hettiarachchi

University of Colombo Faculty of Medicine

Dileepa Ediriweera

University of Kelaniya Faculty of Medicine

Saroj Jayasinghe

University of Colombo Faculty of Medicine

Research article

Keywords: SARS-CoV-2, COVID-19, symptoms, meta-analysis, prevalence

Posted Date: September 4th, 2020

DOI: https://doi.org/10.21203/rs.3.rs-39412/v2

License: () (1) This work is licensed under a Creative Commons Attribution 4.0 International License. Read Full License 


\section{Abstract}

Background: COVID-19 pandemic has resulted in varying clinical manifestations and mortality rates. There is no consensus on the symptomatology that would guide researchers and clinicians.

Objective: The objective was to identify symptoms and their frequencies of COVID-19 with a meta-analysis of studies from several countries.

Data sources: A systematic review using PubMed and Google Scholar data sources and reference tracing were used to identify 7176 articles.

Eligibility criteria: Suitable articles were selected manually with selection criteria and 14 original articles included in meta-analysis.

Data abstraction and analysis: PRISMA guidelines, used for data abstraction and a table was generated by feeding it with numbers and proportions of each symptom described. A meta-analysis was carried out using random effect models on each symptom separately across the studies and their prevalence rates and $95 \%$ confident intervals were calculated.

Results: Selected 14 studies, either cross-sectional or cohort studies are analyzed. There were 2,660 confirmed cases of COVID-19. The majority were from China $(n=2,439,91.7 \%)$ and remainder from the Netherlands, Italy, Korea and India and one article from Europe. There was a total of 32 symptoms identified from the meta-analysis and additional 7 symptoms were identified from reference searching. The most common symptoms were (prevalence $>50 \%$ ): fever (79.56\%, 95\% Cl: 72.17-86.09\%), malaise (63.3\%, 95\% Cl: 53.1 - 73.0\%), cough (56.7. \%, 95\% Cl: 48.6 - 64.6 \%) and cold (55.6\%, 95\% Cl: 45.2 -

$65.7 \%)$. Symptoms of intermediate incidence (5-49\%) were; anosmia, sneezing, ocular pain, fatigue, sputum production, arthralgia, tachypnea, palpitation, headache, chest tightness, shortness of breath, chills, myalgia, sore throat, anorexia, weakness, diarrhea, rhinorrhea, dizziness, nausea, altered level of consciousness, vomiting and abdominal pain. Rare symptoms (<5\%): tonsil swelling, haemoptysis, conjunctival injection, lymphadenopathy and rash.

Conclusion and implications of key findings: We found (25/32, from meta-analysis) symptoms to be present in $=>5 \%$ of cases which could be considered as "typical" symptoms of COVID-19. The list of symptoms we identified is different from those documents released by the WHO, CDC, NHS, Chinese CDC, Institute Pasteur and Mayo Clinic. The compiled list would be useful for future researchers to document a comprehensive picture of the illness.

\section{Background}

Severe acute respiratory syndrome coronavirus 2 (SARS-CoV-2), the strain of coronavirus that causes coronavirus disease 2019 (COVID-19) has resulted in a pandemic with varying clinical manifestations ${ }^{1,2}$. It has affected 216 countries or territories across the globe. Since the outbreak, it has claimed more than 423,000 lives and infected 7.5 million by mid-June 2020 according to the World Health Organization (WHO) ${ }^{3}$. As COVID-19 spreads rapidly studies characterizing its clinical syndromes report a range of clinical features that differ from classic SARS like respiratory illness. This could be a result of host genetic and environmental factors or the virulence factors of the virus. There have been an estimated 198 sites in the SARS-CoV-2 genome that have undergone recurrent independent mutations suggesting an ongoing adaptation of COVID-19 to its human host ${ }^{4}$. Currently the clinical manifestations of the novel coronavirus portray a picture of multisystem involvement. The spectrum of clinical manifestations ranges from an asymptomatic carrier state to mild symptomatic disease with full recovery or progression to multi organ dysfunction and even sudden death. The classic clinical presentations when it was initially described was cough, shortness of breath or difficulty in breathing or at least two of the following symptoms including fever, chills, muscle pain, headache, sore throat and new loss of taste or smell ${ }^{5}$. Some presentations e.g. thromboembolism leading to multi-organ failure, stroke and cardiac complications like ischemic and rhythm abnormalities and skin manifestations such as petechial rashes and gastrointestinal symptoms; diarrhea, nausea and vomiting, which were thought as 'atypical' initially were found to be frequent as more cases with those presentations started emerging. Although many symptoms are described in literature, collective data from across different continents is no available. There is no consensus on 'symptoms of COVID-19' established up to now. We conducted this systematic review and meta-analysis to identify the common and uncommon symptoms of COVID-19 by analyzing selected studies around the world.

\section{Methods}

Study design: Systematic review with meta-analysis

We followed the recommendations of PRISMA and Meta-analysis of Observational Studies in Epidemiology (MOOSE) guidelines ${ }^{6}$.

Selection of studies and extraction of data: We (first two investigators themselves) used PubMed and Google scholar data bases to extract data. We searched the PubMed data base for suitable articles using the key words; "Symptoms of COVID-19 or 2019-nCoV or SARS-CoV-2" which produced 2761 articles on June $02^{\text {nd }}$ 2019. Google scholar search with the same terms produced 2920 articles. "Clinical manifestations of COVID-19 or 2019-nCoV or SARS-CoV-2" produced 1466 articles on the same day. Further Google searches were carried out using references to trace important articles. This process of selection of articles is depicted in the flow diagram 01.

Initial search results were first screened by the title and abstract. We included peer-reviewed articles that reported demographical, clinical features of cases confirmed using real-time reverse transcriptase polymerase chain reaction (RT-PCR). Only the original articles which had evaluated the clinical manifestations were included, with a minimum number of cases of 20 for the meta-analysis. Thus, case reports, review articles, letters and opinions were not included for meta-analysis. The inclusion and exclusion criteria are given below:

Inclusion criteria

Page 2/15 
1. Original studies evaluating symptoms of COVID-19 published before 2 June 2020 on persons confirmed with a positive PCR.

2. Predominately adult studies

3. Studies with more than 90 cases for China and at least 20 cases for other countries

4. Studies conducted in any country

5. Articles published in English language

\section{Exclusion criteria}

1. Predominately paediatric studies

2. Those articles that had not stated the frequencies and/or percentages of incidence of symptoms of COVID-19

3. Studies with less than 90 cases for China and less than 20 cases for other countries

4. Articles published in languages other than English

Please note that there were several studies from China; authors intentionally limited the number of studies from China when adequate numbers were included. This was to enable the inclusion of a diverse population in order to improve the generalizability of findings. We have limited the symptom analysis to mainly adult population, excluding primarily paediatric studies considering the potential variation in symptomatology, target groups and expertise of the authors. The authors' fluency in languages is limited to English on published articles leaving those published in other languages, excluded.

Study population: we included data from 14 studies, collecting 2660 individuals in to the analysis. Ages ranged from 0 to 94 years. It was not possible to calculate means and modes due to differences in the data given in the studies. However, the age and sex parameters are given separately for each study in table 01.

The disease severity included mild, moderate, severe/ critical and fatal representing a wider spectrum of disease. Each symptom was taken separately across the studies, including only those tested for that symptom, to avoid confounding by the investigator 'not checking' for the particular symptom. Meta-analysis was carried out studying each symptom separately and their frequencies were calculated and ranked in order. Figure 1 demonstrates the prevalence of all the symptoms and further describes the results of meta-analysis for each symptom separately. These symptoms are illustrated with the relevant system involved in Figure 2.

Among the selected studies for symptom analysis, 9 were from China ${ }^{7-13}$, one study per each country included from Netherlands ${ }^{14}$, India ${ }^{15}$, Korea ${ }^{16}$ and Italy

${ }^{17}$. Another article by Spiteri $\mathrm{G}$ et.al was included which represented the first 38 cases in Europe ${ }^{18}$. A large study which included data from 5700 coVID-19 patients in New York, was not include in to the meta-analysis. This is because the clinical characteristics assessed in this study were only fever and tachypnea present at triage. Fever was present only at triage in $30.7 \%$ and tachypnea in $17.3 \%$ of cases ${ }^{19}$. Here the symptoms before and after the triage was not taken in to account thus limiting the feasibility in our analysis ${ }^{19}$. Several other similar studies were excluded from the meta-analysis concerning the selection criteria; doubts raised on accuracy of data, inadequate information on symptoms studied etc. ${ }^{31-43}$.

Methodology and results of these articles were also studied prior to selection, to assure the quality of information. After assessing the suitability of the articles, we selected 14 original studies for the meta-analysis. Those articles were used to generate a table consisting of sample size, number, percentage and prevalence of each symptom. The findings are presented in Table 1 as the Characteristics of studies. All the patients included were diagnosed to have COVID19 by detection of nucleic acids (viral RNA detection by Reverse Transcription Polymerase Chain Reaction - RT-PCR).

Statistical analysis: All the symptoms encountered were considered for the analysis. Some symptoms were identified in all the studies (e.g. fever and cough), but certain symptoms were only described in one study (e.g. common cold, tonsil swelling, sneezing, palpitation, conjunctival congestion/ injection anosmia, rash, lymphadenopathy and malaise). Therefore, each symptom was considered separately and meta-analysis was carried out to obtain the prevalence of each symptom across all the studies. The sample size and number of events per each symptom in each study was considered in the analysis. Freeman-Tukey double arcsine transformation with inverse variance method was used to consider individual study weights. The overall prevalence of symptoms across studies along with $95 \%$ confidence intervals was calculated and symptoms were ranked in the ascending order as depicted in figure 1 . R programming language version $3.6 .3^{22}$ and Meta package ${ }^{23}$ were used in the analysis.

\section{Results}

A total of 14 articles with original data describing the clinical manifestations of COVID-19 were retrieved. The largest study was done in China by Guan et.al ${ }^{7}$. Owing to the novelty of the current pandemic there were heterogeneity among the available data and not all symptoms were mentioned. The ages of patients varied from 0 to 94 years. All the studies were descriptive cross sectional or cohort studies and their characteristics are summarized in the Table 1.

\section{Clinical manifestations of COVID-19}

We identified 32 symptoms mentioned in 14 studies. Table 2 summarizes clinical manifestation from those selected original articles with their frequencies. Those seen in more than $5 \%$ of the study populations were considered common and those less than $5 \%$ as uncommon.

\section{Ranking of symptoms}

The most prevalent clinical symptoms were fever (79.56\%, 95\% Cl: 72.17-86.09\%), malaise (63.3\%, 95\% Cl: 53.1 - $73.0 \%)$, cough (56.7. \%, $95 \%$ Cl: 48.6 - 64.6 $\%)$ and cold $(55.6 \%, 95 \% \mathrm{Cl}: 45.2-65.7 \%)$ observed in more than $50 \%$ of the study population. Anosmia $(46.8 \%, 95 \% \mathrm{Cl}$ : $35.9-57.9 \%)$, sneezing (40\%, $95 \% \mathrm{Cl}$ 
30.1-50.4\%), fatigue (37.1\%, 95\% Cl: 27.8-47.0\%) and ocular pain (34.4\%, 95\% Cl: $24.9-44.6 \%)$ are also quite common occurring in $>30 \%$ of cases. Gastrointestinal symptoms are also seen frequently; anorexia (17.6\%, 95\% Cl; 4.4-36.8\%), diarrhea (8.3\%, 95\% $\mathrm{Cl}$; 4.4-13.2), nausea (6.6\%, 95\% Cl; 4.1-9.6\%) and vomiting (5.0\%, 95\% Cl: $2.9-7.5 \%)$. According to our findings uncommon symptoms ( $<5 \%)$ were tonsil swelling, hemoptysis, conjunctival injection/congestion, rash and lymphadenopathy. All those with a prevalence $>/=5 \%$ were considered common and therefore 'typical symptoms' of COVID-19.

There were symptoms noted only in one study (sneezing, tonsil swelling, cold, conjunctival injection/ congestion, ocular pain, rash, lymphadenopathy, anosmia and malaise) thus giving a poor statistical confidence on prevalence. Ageusia and hypogeusia (loss and reduced taste sensation) were not identified from the meta-analysis but were well reported from several regions including Europe ${ }^{57}$, Korea ${ }^{58}$ and Italy ${ }^{59}$. Jerome Echien et al. reported in their multicenter European study, that the ageusia occurred in $21.1 \%$ and hypogeusia in $78.9 \%$ of 342 participated COVID-19 patients. He further describes postnasal drip, face pain/ heaviness, ear pain and dysphagia under otolaryngological complaints ${ }^{58}$. Francesco Freni et al. describes symptoms related to head and neck district by evaluating 50 confirmed cases of COVID-19. They have identified eye dryness (32/50, i.e. $64 \%)$, xerostomia (16/50, i.e. $32 \%)$ and tinnitus (10/50, i.e. $20 \%)$ in addition to what so far described in our study ${ }^{59}$.

\section{Discussion}

This study was designed to identify the symptoms of COVID-19 and to rank them according to their frequencies of occurrence in a globally representative sample. This was difficult as the disease is novel and new symptoms and complications were frequently been reported. Our study recognizes 32 symptoms of coronavirus disease, which represent most organs and systemic features, thus defining this disease as a multisystem syndrome rather than a respiratory disease. There was no clear consensus as to what are the symptoms of novel corona virus disease until now. Manifestations are identified as we learn about it with the spread of the disease. The symptoms identified in the guidelines issued by the World Health Organization (WHO) ${ }^{25}$, The National Health Service (NHS) ${ }^{26}$, The Centers for Disease Control and Prevention (CDC) ${ }^{27}$, Chinese Center for Disease Control and Prevention (Chinese CDC) ${ }^{28}$, Institute Pasteur ${ }^{29}$, Mayo Clinic $^{30}$ and in web-based trackers for self-assessment differ from that reported in our study. This comparison is shown in Table 3.

We also found two studies which used such clinical criteria ${ }^{55-5}$.

We used original studies from different geographic locations having a range of severities to improve the generalizability of the information. However, nine studies representing about $90 \%$ of study population is from China, giving a publication bias for our statistical analysis. There is a significant variation in proportions of each symptom across countries and regions. This variability of presentations is likely to be due to the differences in demography of sample, virulence of strain of COVID-19, aggregation of severe cases in to certain centers with higher facilities and milder cases in to other care centers and variations in host response (both genetic and immunological) in different populations.

Wider spectrum of disease severity is covered by the included studies for the meta-analysis. Tostmann et al (14) has studied the COVID-19 in health care workers during a screening test while Chen $\mathrm{T}$ et al ${ }^{(8)}$ included 113 fatal cases thus approaching the far severe aspect of the disease. However, the accessibility to health care facility and some factors that could modify clinical features (e.g pregnancy, co-morbidities of individuals) were not taken in to account. The studies primarily on paediatric and neonatal population were identified but not included in this analysis and suggest the need of a different study for that ${ }^{45-49}$.

Older age, male sex, presence of comorbidities and certain symptoms were associated with poor outcome. The median age in the Italian study was high (median of 67.5 years), which may at least partially explain the higher fatality rates observed in this population ${ }^{(17)}$. Sex-disaggregated data suggests a slight male predominance which was also observed in mortality rates ${ }^{(20)}$. Clinical data associated with disease evolution is critical knowledge especially in a new pandemic. Among the reported cases till February 2020, 14\% of COVID-19 cases were severe, causing pneumonia and shortness of breath, and that of about $5 \%$ of patients had critical disease, including respiratory failure, septic shock, and multi-organ failure ${ }^{(21)}$. Host susceptibility is studied in detail by Shi Yu et al, including 487 patients outside Wuhan. They have developed a host risk score using 3 variables: age, sex and presence or absence of hypertension ${ }^{44}$. Further analyses of the symptoms indicate that, certain symptoms like dyspnoea/ shortness of breath ( $62 \%$ in diseased vs. $31 \%$ in recovered), chest pain ( $49 \%$ in diseased vs. $30 \%$ in recovered) and altered consciousness ( $22 \%$ in diseased vs. $1 \%$ in recovered), are associated with higher mortality ${ }^{(8)}$.

Asymptomatic cases in this study was $9 / 287$ (prevalence $-2.71 \%, 95 \% \mathrm{Cl} 0.96 \%-5.12 \%$ ) using data from articles by Chen $\mathrm{J}{ }^{(9)}$ and Spiteri G ${ }^{(18)}$. This might not reveal the true picture, because a large-scale screening tests done on populations at risk needed to assess this. However, a study done in Japanese Diamond Princess Cruise ship by Mizumoto K et el. shows valuable results. Here 3,711 patients were kept quarantined after finding one patient with COVID-19. Out of all, 634 cases became positive and 306 (48.3\%) cases were symptomatic and $328(51.7 \%)$ were asymptomatic (24)

In this study, we did not concentrate on the chronology of development of symptoms and complications which is also very important for clinicians when assessing patients, and need to be addressed in detail separately. However, temporal clinical progression has been assessed by $\mathrm{Chen} \mathrm{J}$ et al ( $\mathrm{N}=249$ ) in their study ${ }^{9}$. There had been reports of possible 'reactivation' of COVID-19 after recovering from the first infection ${ }^{37}$; the symptoms of such cases are not taken into this review.

The results of our systematic review highlight the common and uncommon clinical symptoms which will help clinicians across the globe in the diagnosis and management of suspected cases of COVID-19, especially during the early phase. This will help in defining the disease presentation and improves diagnostic skills. These common and uncommon symptoms could be utilized in studying patients and designing future research.

There are a multitude of other uncommon or rare manifestations of COVID-19 not described in these studies presented from many countries that have been mainly the focus of case reports ${ }^{50-54}$. The pathophysiology of novel corona virus disease is not yet well understood. However, there are satisfactory evidence 
to suggest mechanisms such as widespread thrombosis, microangiopathy and vascular angiogenesis, neurotrophic actions (both central and peripheral) and actions involving renin-angiotensin-aldosterone system are involved in the pathogenesis ${ }^{59-62}$.

\section{Limitations}

Some symptoms assessed were only present in one or two studies and other studies have not recorded them or not inquired about them making them

statistically less reliable on their frequencies.

We have not focused on the chronology of symptom development and complications. Reports in languages other than English were not included

\section{Conclusions}

There are 32 symptoms of COVID-19 representing multiple organs and systemic features. Fever is the most common symptom followed by malaise, cough, cold and anosmia. Researchers and clinicians should be aware of a comprehensive list of symptoms to describe the illness and for research.

\section{Abbreviations}

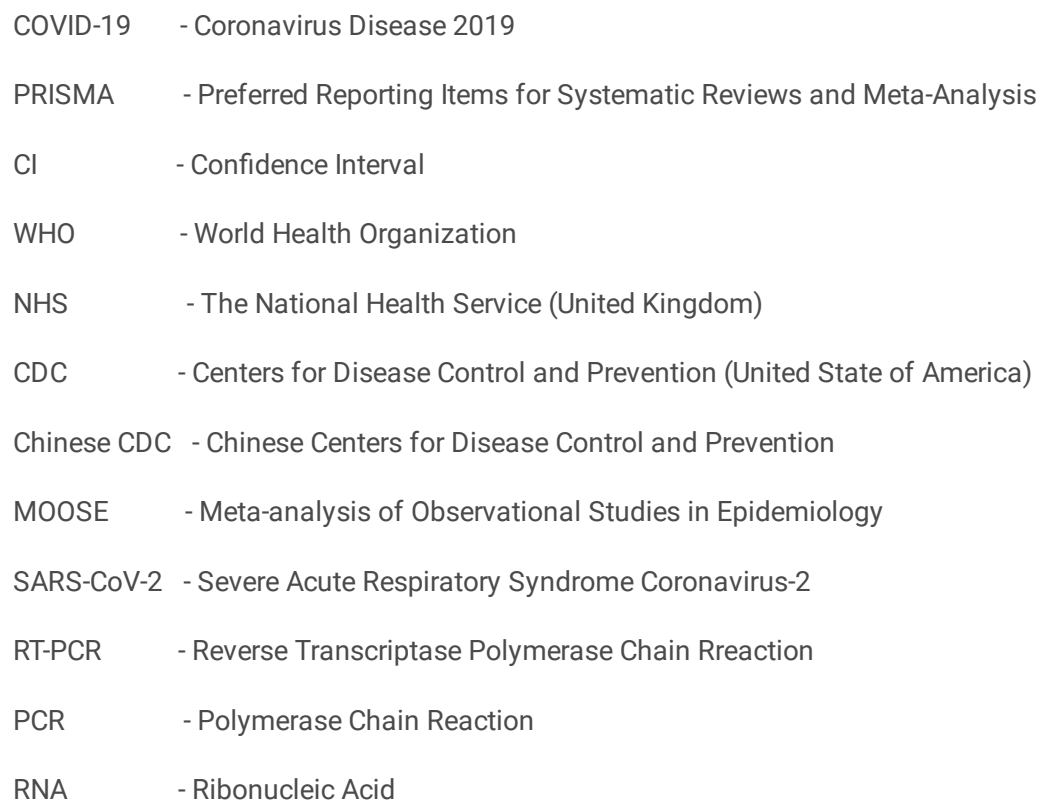

\section{Declarations}

Ethics approval and consent to participate: Not applicable

Consent for publication: Not applicable

Availability of data and materials: The pooled articles, data-sheets and analytic results are available with the authors for future references Competing interests: There are no competing interests.

Funding: No funding involved in this study and manuscript writing

Authors' contributions:

CG: Conceptualization, search of data sources, initial draft writing and updating manuscript

DH: Search of data sources, Initial draft writing, updating manuscript, and designing figure 02 info graphic. .

DE: Meta-analysis and compilation of statistics section of manuscript

SJ: Update and finalizing the manuscript.

All authors have read and approved the manuscript

Acknowledgements: We wish to thank Ms. Sajini Wickramasinghe for her contribution to the info graphic

Ethical concerns: We included the data from published literature and the consent was not applicable data collection and for publications. 


\section{References}

1. Vincent $\mathrm{J}$ et al. A novel coronavirus emerging in China - key questions for impact assessment. N ENGL J MED 382;8 February 20,2020

2. Qiu H. Clinical and epidemiologia features of 36 children with coronavirus disease 2019 (COVD-19) in Zhejiang, China: an observational cohort study. Lancet Infect Dis 2020;20: 689-96

3. https://www.who.int/docs/default-source/coronaviruse/situation-reports/20200521-covid-19-sitrep-122.pdf?sfvrsn=24f20e05_2

4. Dorp V, Lucy, et al. "Emergence of genomic diversity and recurrent mutations in SARS-CoV-2." Infection, Genetics and Evolution(2020): 104351.

5. https://www.cdc.gov/coronavirus/2019-ncov/symptoms-testing/symptoms.html?fbclid=IwAR0014Hs3DpWCmiKmrWV7fqsdAbF96zeMDkt1zZy4vsf9tWEHa-jcxc-XA

6. Moher, David, et al. "Preferred reporting items for systematic reviews and meta-analyses: the PRISMA statement." PLoS med7 (2009): e1000097.

7. Guan W et al. Clinical characteristics of coronavirus disease 2019 in China. N Engl J Med. 28 Feb 2020. DOI: 10.1056/NEJMoa2002032

8. Chen T et al. Clinical characteristics of 113 deceased patients with coronavirus disease 2019: retrospective study. BMJ 2020;368:m1091

9. Chen J et al. Clinical progress of patients with COVID-19 in Shanghai, China. Journal of infection 80 (2020) el-e6

10. Zhou F et al. Clinical course and risk factors for mortality of adults inpatients with COVID-19 in Wuhan, China: a retrospective cohort study. Lancet 2020; 395: 1054-62

11. Zheng F et al. Clinical characteristics of 161 cases of corona virus disease 2019 (COVID-19 in Changsha. Eur Rev Med Pharmacol Sci 2020; 24:3404-3410

12. Chen $\mathrm{N}$ et al. Epidemiological and clinical characteristics of 99 cases of 2019 novel coronavirus pneumonia Wuhan, Chins: a descriptive study. Lancet 2020; 395:507-13

13. Zhao X Y et al. Clinical characteristics of patients with 2019 coronavirus disease in a non-Wuhan area of Hubei province, China: a retrospective study. Zhao et al. BMC infectious Diseases 2020 20:311

14. Tostmann A et al. Strong associations and moderate predictive value of early symptoms for SARS-CoV-2 test positivity among healthcare workers, the Netherlands, March 2020.

15. Gupta $\mathrm{N}$ et al. Clinical and epidemiologic profile of the initial COVID-19 patients at a tertiary care centre in India. Monaldi Archives for Chest Diseases 2020; $90: 1294$

16. Kim E S et al. Clinical course and outcomes of patients with severe acute respiratory syndrome coronavirus 2 infection: a preliminary report of first 28 patients from the Korean cohort study on COVID-19. J Korean Med Sci. 2020 Apr 6; 35(13):e142

17. Colaneri Marta, Sacchi Paolo, Zuccaro Valentina, Biscarini Simona, Sachs Michele, Roda Silvia, Pieri Teresa Chiara, Valsecchi Pietro , Piralla Antonio , Seminari Elena , Di Matteo Angela, Novati Stefano, Maiocchi Laura , Pagnucco Layla, Tirani Marcello, Baldanti Fausto , Mojoli Francesco , Perlini Stefano, Bruno Raffaele, the COVID19 IRCCS San Matteo Pavia Task Force. Clinical characteristics of coronavirus disease (COVID-19) early findings from a teaching hospital in Pavia, North Italy, 21 to 28 February 2020. Euro Surveill. 2020;25(16):pii=2000460. https://doi.org/10.2807/15607917.ES.2020.25.16.2000460

18. Spiteri Gianfranco, Fielding James, Diercke Michaela , Campese Christine, Enouf Vincent, Gaymard Alexandre, Bella Antonino , Sognamiglio Paola , Sierra Moros, Maria Jose, Riutort Antonio Nicolau , Demina Yulia V. , Mahieu Romain, Broas Markku , Bengner Malin , Buda Silke, Schilling Julia , Filleul Laurent, Lepoutre, Agnes, Saura Christine, Mailles Alexandra, Levy-Bruhl Daniel, Coignard Bruno, Bernard-Stoecklin Sibylle, Behillil Sylvie, van der Werf Sylvie, Valette Martine, Lina Bruno , Riccardo Flavia , Nicastri Emanuele, Casas Inmaculada , Larrauri Amparo, Salom Castell Magdalena , Pozo Francisco , Maksyutov Rinat A. , Martin, Charlotte, Van Ranst Marc , Bossuyt Nathalie, Siira Lotta , Sane Jussi , Tegmark-Wisell Karin , Palmerus Maria , Broberg Eeva K. , Beaute Julien, Jorgensen Pernille, Bundle Nick , Pereyaslov Dmitriy , Adlhoch Cornelia , Pukkila Jukka, Pebody Richard, Olsen Sonja , Ciancio Bruno Christian . First cases of coronavirus disease. 2019 (COVID-19) in the WHO European Region, 24 January to 21 February 2020 . Euro Surveill. 2020;25(9):pii=2000178. https://doi.org/10.2807/1560-7917.ES.2020.25.9.2000178

19. Richardson S et al. Presenting characteristics, comorbidities and outcomes among 5700 patients hospitalized with COVID-19 in New York city are. JAMA. 2020:323(20):2052-2059. Doi:10,1001/jama.2020.6775

20. Wenham, Clare, Julia Smith, and Rosemary Morgan. "COVID-19: the gendered impacts of the outbreak." The Lancet10227 (2020): 846-848.

21. Mahase, Elisabeth. "Coronavirus: covid-19 has killed more people than SARS and MERS combined, despite lower case fatality rate." (2020).

22. R Core Team (2020). R: A language and environment for statistical computing. R Foundation for Statistical Computing, Vienna, Austria. URLhttps://www.R-project.org/.

23. Balduzzi S, Rücker G, Schwarzer G (2019), How to perform a meta-analysis with R: a practical tutorial, Evidence-Based Mental Health.

24. Mizumoto K, Kagaya K, Zerbeski A and Gerardo C. Estimating the asymptomatic proportion of coronavirus disease 2019 (COVID-19) cases on board the Diamond prince cruise ship, Yokohama, japan, 2020.

25. World Health Organization (WHO). Coronavirus disease (COVID-19) pandemic. https://www.who.int/emergencies/diseases/novel-coronavirus2019/question-and-answers-hub/q-a-detail/q-a-coronaviruses. Accessed May 302020

26. National Health Service (NHS). Coronavirus (COVID-19). https://www.nhs.uk/conditions/coronavirus-covid-19/check-if-you-have-coronavirus-symptoms/. Accessed May 302020

27. Center for Disease Control and Prevention (CDC). Corornavirus Disease 2019. https://www.cdc.gov/coronavirus/2019-ncov/symptomstesting/symptoms.html. Accessed May 302020

28. Chinese center for disease control and prevention. COVID19. http://www.chinacdc.cn/en/COVID19/202002/P020200306358351973919.pdf. Accessed May 302020

Page 6/15 
29. Institut Pasteur. COVID-19 disease (Novel Coronavirus). https://www.pasteur.fr/en/medical-center/disease-sheets/covid-19-disease-novelcoronavirus\#symptoms. Accessed May 302020

30. Mayo Clinic. Coronavirus disease 2019 (COVID-19).. https://www.mayoclinic.org/diseases-conditions/coronavirus/symptoms-causes/syc-20479963. Accessed May 302020

31. Huang $C$ et al. Clinical features of patients infected with 2019 novel coronavirus in Wuhan, China. Lancet 2020; 395: 497-506

32. Zhu W et al. Initial clinical features of suspected coronavirus disease 2019 in two emergency departments outside of Hubei, China. J Med Virol. 2020;1-8.

33. Arentz $\mathrm{M}$ et al. Characteristics and outcomes of 21 critically ill patients with COVID-19 in Washington state. JAMA April 28,2020 Volume 323 , Number 16

34. Li Qun et al. Early transmission dynamics in Wuhan, China, of novel Coronavirus- infected pneumonia. N Engl J Med 2020;382:1199-207

35. Yan $Y$ et al. The first 75 days of novel Coronavirus (SARS-CoV-2) outbreak: recent advances, prevention and treatment. J. Environ. Res. Public Health 2020, 17, 2323; doi:10.3390/ijerph17072323

36. Liu K C et al. CT manifestations of coronavirus disease- 2019: A retrospective analysis of 73 cases by disease severity. European Journal of Radiology 126 (2020) 108941

37. Ye G et al. Clinical characteristics of severe acute respiraotory syndrome coronavirus 2 reactivation. Journal of Infection 80 (2020) e14-e17

38. Korean society of infectious diseases and Korea Centers for Disease Control and Prevention. Analysis on 54 mortality cases of Coronavirus Disease 2019 in the Republic of Korea from January 19 to March 10, 2020. J Korean Med Sci. 2020 Mar 30;35(12):e132

39. Hu, Z., Song, C., Xu, C., Jin, G., Chen, Y., Xu, X., Ma, H., Chen, W., Lin, Y., Zheng, Y., et al. (2020). Clinical characteristics of 24 asymptomatic infections with COVID-19 screened among close contacts in Nanjing, China. Sci China Life Sci 63, https://doi.org/10.1007/s11427-020-1661-4

40. Chen $\mathrm{G}$ et al. Clinical and immunological features of severe and moderate coronavirus disease 2019. J Clin Invest. 2020;130(5):2620-2629. https://doi.org/10.1172/JCl137244.

41. Xu Xiao-Wei et al. Clinical findings in a group of patients infected with the corona virus (SARS-Cov-2) outside of the Wuhan, China: retrospective case series. BMJ 2020;368:m606 http://dx.doi.org/10.1136/bmj.m606

42. Wang L, Gao Y-hua, lou L-L, et al. The clinical dynamics of 18 cases of COVID-19 outside of Wuhan, China. Eur Respir J 2020; in press (https://doi.org/10.1183/13993003.00398-2020)

43. Pung R et al. Investigation of three clusters of COVID-19 in Singapore: implications for surveillance and response measures. Lancet 2020; 395 : 1039-46

44. Shi Y et al. Host susceptibility to severe COVID-19 and establishment of a host risk score: findings of 487 cases outside Wuhan. Shi et al. Critical Care (2020) $24: 108$

45. Hong H, Wang Y, Chung H-T, Chen C-J, Clinical characteristics of novel coronavirus disease 2019 (COVID-19) in newborns, infants and children, Pediatrics and Neonatology, https://doi.org/10.1016/j.pedneo.2020.03.001.

46. Chang T-H et al., Clinical characteristics and diagnostic challenges of pediatric COVID-19: A systematic review and meta-analysis, Journal of the Formosan Medical Association, https://doi.org/10.1016/j.jfma.2020.04.007

47. Xia W et al. Clinical and CT features in pediatric patients with COVID-19 infection: Different points from adults. Pediatric Pulmonology. 2020;55:11691174.

48. Su L et al. The different clinical characteristics of corona virus disese cases between children and their families in China - the character of children with COVID-19. Emerging Microbes \& Infections 2020, VOL 9: 707-713.

49. Zheng F et al. Clinical characteristics of children with Coronavirus disease 2019 in Hubei, China. Current Medical Science. DOI https://doi.org/10.1007/s11596-020-2172-6. 40(2):275-280,2020

50. Kotfis K et al. COVID-19: ICU delirium management during SARS-CoV-2 pandemic. Critical Care (2020) 24:176.

51. Zhao H, Shen D, Zhou H, Liu J, Chen S. Guillain-Barré syndrome associated with SARS-CoV-2 infection: causality or coincidence?. https://doi.org/10.1016/S1474-4422(20)30109-5

52. Sun R, Liu H, Wang X. Mediastinal emphysema, giant bulla and pneumothorax developed during the course of COVID-19 pneumonia. Korean J Radiol 2020:21(5):541-544.

53. Chen C, Zhou Y. Wang D. SARS-CoV-2: a potential novel etiology of fulminant myocarditis. https://doi.org/10.1007/s00059-020-04909-z

54. Nicastri Emanuele , D’Abramo Alessandra , Faggioni Giovanni , De Santis Riccardo, Mariano Andrea , Lepore Luciana , Molinari Filippo , Petralito Giancarlo , Fillo Silvia , Munzi Diego, Corpolongo Angela, Bordi Licia , Carletti Fabrizio, Castiletti Concetta , Colavita Francesca , Lalle Eleonora , Bevilacqua Nazario, Giancola Maria Letizia , Scorzolini Laura , Lanini Simone, Palazzolo Claudia , De Domenico Angelo, Spinelli Maria Anna , Scognamiglio Paola , Piredda Paolo, lacomino Raffaele, Mone Andrea, Puro Vincenzo , Petrosillo Nicola, Battistini Antonio, Vairo Francesco, Lista Florigio, Ippolito Giuseppe, on behalf of INMI and the Italian Army COVID-19 study groups . Coronavirus disease (COVID-19) in a paucisymptomatic patient: epidemiological and clinical challenge in settings with limited. community transmission, Italy, February 2020. Euro Surveill.

2020;25(11):pii=2000230. https://doi.org/10.2807/1560-7917.ES.2020.25.11.2000230

55. Boulware DR, Pullen MF, Bangdiwala AS, et al. A Randomized Trial of Hydroxychloroquine as Postexposure Prophylaxis for Covid-19 [published online ahead of print, 2020 Jun 3]. N Engl J Med. 2020;NEJMoa2016638. doi:10.1056/NEJMoa2016638

Lother SA, Abassi M, Agostinis A, et al. Post-exposure prophylaxis or pre-emptive therapy for severe acute respiratory syndrome coronavirus 2 (SARS-CoV2): study protocol for a pragmatic randomized-controlled trial [published online ahead of print, 2020 May 7]. Can J Anaesth. 2020;1-11.

doi:10.1007/s12630-020-01684-7 
56. Standardized surveillance case definition and national notification for 2019 novel coronavirus disease. (COVID9)

https://cdn.ymaws.com/www.cste.org/resource/resmgr/2020ps/Interim-20-ID-01_COVID-19.pdf

57. Jerome R. L et al. Olfactory and gustatory dysfunctions as a clinical presentationof mild-to-moderate forms of the coronavirus (COVID-19): a muticenter European study. European Archives of Oto-Rhino-Laryngology. https://doi.org/10.1007/s00405-020-05965-1

58. Yonghyun L, Pokkee M, Seonggu L, Shin W K. Prevalence and duration of acute loss of smell or taste in COVID-19 patients. J Korean Med Sci. 2020 May 11;35(18):e174.doi: 10.3346/jkms.2020.35.e174

59. Francesco $\mathrm{F}$ et al. Symptomatology in the head and neck district in coronavirus disease (COVID-19): A possible neuroinvasive action of SARS-CoV-2. Am J Otolaryngol 41 (2020) 102612

60. Maxmilian A et al. Pulmonary vascular endothelialitis, thrombosis, and angiogenesis in COVID-19. N ENGL J MED 383;2. July 9, 2020

61. Gustave $\mathrm{C}$ et al. The neurology of COVID-19 revisited: A proposal from the Environmental Neurology Specialty Group of the World Federation of Neurology to implement international neurological registries. Journal of the Neurological Sciences 414 (2020) 116884.

62. Muthiah V et al. Renin-angiotensin-aldosterone system inhibitors in patients with COVID-19. N ENGL J MED 382;17. April 23, 2020

\section{Tables}

Table1. Clinical characteristics of the studies used for meta-analysis 


\begin{tabular}{|c|c|c|c|c|c|}
\hline Study & $\begin{array}{l}\text { Age (years)/ } \\
\text { Sex }\end{array}$ & $\begin{array}{l}\text { Study design } \\
\text { and rating of } \\
\text { quality of } \\
\text { evidence }^{\mathrm{a}}\end{array}$ & $\begin{array}{l}\text { Institute(s)/ } \\
\text { Geography }\end{array}$ & Composition & Comments or additional information \\
\hline $\begin{array}{l}\text { CHINA } \\
\text { Guan W } \\
\mathrm{N}=1099\end{array}$ & $\begin{array}{l}\text { median age of } \\
47 \text {, only } 9 \text { cases } \\
\text { below } 14 \text { and } \\
153 \text { above } 65 \text {, } \\
\text { predominantly } \\
\text { males } 58.1 \%\end{array}$ & $\begin{array}{l}\text { Retrospective } \\
\text { Cohort study } \\
\text { Rating } 3\end{array}$ & $\begin{array}{l}552 \text { hospitals } \\
\text { distributed in } 30 \\
\text { provinces, } \\
\text { autonomous } \\
\text { regions, and } \\
\text { municipalities in } \\
\text { mainland } \\
\text { China }\end{array}$ & $\begin{array}{l}\text { hospitalized as well as from } \\
\text { outpatient departments (OPD) }\end{array}$ & $\begin{array}{l}\text { Composition may represent wider } \\
\text { spectrum of the disease from mild to } \\
\text { severe. }\end{array}$ \\
\hline $\begin{array}{l}\text { CHINA } \\
\text { Chen T } \\
\mathrm{N}=274\end{array}$ & $\begin{array}{l}\text { median age } \\
62.0 \text { [44.0-70.0] } \\
\text { with } 53 \text { below } \\
40 \text { and } 153 \\
\text { above } 60 \text { and } \\
62 \% \text { were males }\end{array}$ & $\begin{array}{l}\text { Retrospective } \\
\text { case series } \\
\text { Rating } 4\end{array}$ & Tongji Hospital & $\begin{array}{l}\text { Only moderate-severe or critically ill } \\
\text { patients have been included. OPD } \\
\text { cases not included } \\
113 / 274 \text { died }\end{array}$ & $\begin{array}{l}\text { Symptoms of those survived are mostly } \\
\text { comparable to those died. } \\
\text { Dyspnoea was commoner } 62 \% \text { in those } \\
\text { died and only } 31 \% \text { in those recovered }\end{array}$ \\
\hline $\begin{array}{l}\text { CHINA } \\
\text { Chen J } \\
\mathrm{N}=249\end{array}$ & $\begin{array}{l}\text { The median age } \\
\text { was } 51 \text { years } \\
\text { old (IQR, 36-64 } \\
\text { years), } \\
\text { and } 126(50.6 \%) \\
\text { were male }\end{array}$ & $\begin{array}{l}\text { Retrospective } \\
\text { cross } \\
\text { sectional } \\
\text { study } \\
\text { Rating } 3\end{array}$ & $\begin{array}{l}\text { Shanghai Public } \\
\text { Health Clinical } \\
\text { Centre (SPHCC)- } \\
\text { hospitalized }\end{array}$ & $\begin{array}{l}22(8.8 \%) \text {-admitted to ICU } \\
215(86.3 \%) \text { - were discharged } \\
2(0.8 \%) \text {-died }\end{array}$ & $\begin{array}{l}\text { Has studied the temporal clinical } \\
\text { progression ; Median duration of fever } \\
\text { was } 10 \text { days ( } 95 \% \mathrm{Cl}-8-11 \text { days) }\end{array}$ \\
\hline $\begin{array}{l}\text { CHINA } \\
\text { Shou F } \\
N=191\end{array}$ & $\begin{array}{l}\text { age } 46 \text { to } 67 \\
62 \% \text { males }\end{array}$ & $\begin{array}{l}\text { Retrospective } \\
\text { Cohort study } \\
\text { Rating } 3\end{array}$ & Multicentre & $\begin{array}{l}\text { They represent } 50(26 \%) \text { ICU admitted } \\
\text { cases, and } 54(28 \%) \text { deaths. Disease } \\
\text { severity ranges from general ( } 38 \%) \text {, } \\
\text { severe }(35 \%) \text { and critical }(28 \%) \text {, thus } \\
\text { excluding the milder fraction of the } \\
\text { severity spectrum }\end{array}$ & \\
\hline $\begin{array}{l}\text { CHINA } \\
\text { Sheng F } \\
\mathrm{N}=161\end{array}$ & $\begin{array}{l}\text { age } 45 \text { (IQR } \\
33.5-57) \\
49.7 \% \text { males }\end{array}$ & $\begin{array}{l}\text { Retrospective } \\
\text { Cross } \\
\text { sectional } \\
\text { study } \\
\text { Rating } 4\end{array}$ & $\begin{array}{l}\text { Changsha Public } \\
\text { Health treatment } \\
\text { Center (CPHC) }\end{array}$ & $\begin{array}{l}30 \text { of } 161 \text { were taken as severe and } \\
\text { the rest were non-severe. }\end{array}$ & $\begin{array}{l}\text { There was a statistically significant } \\
\text { difference in age between the severe } \\
\text { and } \\
\text { non-severe groups }(p<0.05) \text {, with }\end{array}$ \\
\hline $\begin{array}{l}\text { CHINA } \\
\text { Wang D } \\
\mathrm{N}=138\end{array}$ & $\begin{array}{l}\text { The median age } \\
56 \text { (IQR, } 42-68) \text {, } \\
\text { age range } 22- \\
92) \\
75(73.9 \%) \text { were } \\
\text { men }\end{array}$ & $\begin{array}{l}\text { Retrospective } \\
\text { case series } \\
\text { Rating } 3\end{array}$ & $\begin{array}{l}\text { Zhongnan } \\
\text { Hospital of } \\
\text { Wuhan } \\
\text { University }\end{array}$ & $\begin{array}{l}36 / 138 \text { were admitted ICU and were } \\
\text { older (median age, } 66 \text { [IQR, } 57-78] \text { ) } \\
\text { than non-ICU patients (median age of } \\
51 \text { [IQR- } 37-62] \text { ), } P<0.001 \text {. }\end{array}$ & $\begin{array}{l}\text { ICU admitted patients were more likely } \\
\text { to have pharyngeal pain, dyspnoea, } \\
\text { dizziness, abdominal pain and anorexia. }\end{array}$ \\
\hline $\begin{array}{l}\text { CHINA } \\
\text { Lui K } \\
\mathrm{N}=137\end{array}$ & $\begin{array}{l}\text { Age range } 20- \\
83, \text { with median } \\
55+/-16 \text {. } \\
61 / 137(44.5 \%) \\
\text { were males }\end{array}$ & $\begin{array}{l}\text { Retrospective } \\
\text { cross } \\
\text { sectional } \\
\text { study } \\
\text { Rating } 3\end{array}$ & $\begin{array}{l}\text { Respiratory } \\
\text { departments of } \\
\text { nine tertiary } \\
\text { hospitals in } \\
\text { Hubei province }\end{array}$ & $\begin{array}{l}\text { Discharged } 44(32.1 \%) \\
\text { Death } 16(11.7 \%) \\
\text { Inpatient treatment } 77(56.2 \%)\end{array}$ & $\begin{array}{l}\text { Higher mortality rate likely due to more } \\
\text { critical patient cohort involved in the } \\
\text { respiratory wards. }\end{array}$ \\
\hline $\begin{array}{l}\text { CHINA } \\
\text { Chen N } \\
\mathrm{N}=99\end{array}$ & $\begin{array}{l}\text { ages from } 21- \\
82, \text { with a mean } \\
\text { of } 55.5(\mathrm{SD} \\
13.1) \text { and } 67 \% \\
\text { were males }\end{array}$ & $\begin{array}{l}\text { Retrospective } \\
\text { cross } \\
\text { sectional } \\
\text { study } \\
\text { Rating } 4\end{array}$ & $\begin{array}{l}\text { Jinyintan Adult } \\
\text { Hospital in } \\
\text { Wuhan }\end{array}$ & $11(11 \%)$ - died & $\begin{array}{l}49 \% \text { of patients had an exposure to } \\
\text { seafood market in Huanan. } \\
\text { Article gives data only up to } 25 \text { Jan } \\
2020 \text { and outcomes were- } 11 \% \text { deaths/ } \\
31 \% \text { discharged/ rest still hospital }\end{array}$ \\
\hline $\begin{array}{l}\text { CHINA } \\
\text { Zhao XY } \\
\mathrm{N}=91\end{array}$ & $\begin{array}{l}\text { median age } 46 \\
\text { and } 53.8 \% \text { were } \\
\text { male }\end{array}$ & $\begin{array}{l}\text { Crosssectional } \\
\text { study } \\
\text { Rating } 4\end{array}$ & $\begin{array}{l}\text { hospitalized } \\
\text { patients } \\
\text { admitted in } \\
\text { Jingzhou Central } \\
\text { Hospital }\end{array}$ & $\begin{array}{l}30(33 \%) \text { - severely ill } \\
2(2.2 \%) \text { - died } \\
61(67 \%) \text { - only mild disease }\end{array}$ & $\begin{array}{l}\text { Outcomes taken when } 75 \text { (82.4\%) were } \\
\text { still in hospital. }\end{array}$ \\
\hline Study & $\begin{array}{l}\text { Age (years)/ } \\
\text { Sex }\end{array}$ & $\begin{array}{l}\text { Study design } \\
\text { and rating of } \\
\text { quality of } \\
\text { evidence }^{a}\end{array}$ & $\begin{array}{l}\text { Institute(s)/ } \\
\text { Geography }\end{array}$ & Composition & Comments or additional information \\
\hline N'lands & aged $21-60$ & Cross & Radbound & $\begin{array}{l}\text { healthcare workers (HCW), diagnosed } \\
\text { Page 9/15 }\end{array}$ & Symptoms analysed from a questioner \\
\hline
\end{tabular}




\begin{tabular}{|c|c|c|c|c|c|}
\hline $\begin{array}{l}\text { Tostmann } \\
\text { A } \\
\mathrm{N}=90\end{array}$ & $\begin{array}{l}\text { except those } 03 \\
\text { above } 60 \text { and } \\
82.9 \% \text { were } \\
\text { females }\end{array}$ & $\begin{array}{l}\text { sectional } \\
\text { study } \\
\text { Rating } 4\end{array}$ & $\begin{array}{l}\text { university } \\
\text { medical centre, } \\
\text { Nimegen, The } \\
\text { Netherlands }\end{array}$ & $\begin{array}{l}\text { with COVID-19 during a screening } \\
\text { done on } 1,247 \text { mildly symptomatic } \\
\text { HCW }\end{array}$ & $\begin{array}{l}\text { given but only } 803 / 1,247 \text { Health care } \\
\text { workers have responded by filling the } \\
\text { questionnaire. They assessed early } \\
\text { features of disease and the patients } \\
\text { were otherwise healthy. }\end{array}$ \\
\hline $\begin{array}{l}\text { INDIA } \\
\text { Gupta N } \\
\text { N=21 }\end{array}$ & $\begin{array}{l}\text { aged } 16-73 \\
\text { (mean } 40.3 \text { ) } \\
\text { and } 66.7 \% \text { male }\end{array}$ & $\begin{array}{l}\text { Case series } \\
\text { Rating } 4\end{array}$ & $\begin{array}{l}\text { Safdarjung } \\
\text { Tertiary care } \\
\text { Hospital, New } \\
\text { Delhi }\end{array}$ & $\begin{array}{l}\text { None given ICU care and only } \\
\text { developed breathlessness and given } \\
\text { oxygen }\end{array}$ & $\begin{array}{l}\text { None had rhinitis or diarrhoea } \\
61.9 \% \text { of them were frequent travellers } \\
\text { to Italy, and rest to other countries. }\end{array}$ \\
\hline $\begin{array}{l}\text { EUROPE } \\
\text { Spiteri G } \\
\mathrm{N}=38\end{array}$ & $\begin{array}{l}\text { ages } 2-81 \text { with } \\
\text { median } 42.6 \\
\text { and } 25 / 38 \text { were } \\
\text { males }\end{array}$ & $\begin{array}{l}\text { Cross } \\
\text { sectional } \\
\text { study } \\
\text { Rating } 4\end{array}$ & $\begin{array}{l}\text { Belgium (1), } \\
\text { Finland (1), } \\
\text { France (12), } \\
\text { Germany (16), } \\
\text { Italy (3), Russia } \\
\text { (2), Spain (2) } \\
\text { and Sweden (1) }\end{array}$ & $\begin{array}{l}\text { Four needed respiratory support one } \\
\text { French patient died }\end{array}$ & \\
\hline $\begin{array}{l}\text { KOREA } \\
\text { Kim E S } \\
\mathrm{N}=\mathbf{2 8}\end{array}$ & $\begin{array}{l}\text { aged } 42.6+/- \\
13.4 \text { and } 53.6 \% \\
\text { males }\end{array}$ & $\begin{array}{l}\text { Case series } \\
\text { Rating } 4\end{array}$ & Multicentre ${ }^{c}$ & $\begin{array}{l}6(21.4 \%) \text { - needed on oxygen on } \\
\text { admission } \\
\text { None - needed mechanical ventilation } \\
22(78.5 \%) \text { - had pneumonia }\end{array}$ & $\begin{array}{l}\text { None of these needed mechanical } \\
\text { ventilation. }\end{array}$ \\
\hline $\begin{array}{l}\text { Colanerl } \\
\text { M } \\
\mathrm{N}=44\end{array}$ & $\begin{array}{l}\text { aged } 10-94 \text { with } \\
\text { median of } 67.5 \\
\text { and } 28 / 44 \text { were } \\
\text { males }\end{array}$ & $\begin{array}{l}\text { Cross } \\
\text { sectional } \\
\text { survey } \\
\text { Rating } 4\end{array}$ & $\begin{array}{l}\text { single centre in } \\
\text { Pavia, Italy }\end{array}$ & $\begin{array}{l}2 \text { - received sub-intensive care. } \\
3 \text { - admitted to ICU }\end{array}$ & $\begin{array}{l}\text { Two died and } 17 \text { patients had } \\
\text { developed severe disease } \\
\text { Data analysed while } 23 \text { still in hospital. }\end{array}$ \\
\hline
\end{tabular}

a. Quality Rating Scheme for Studies and Other Evidence

1. Properly powered and conducted randomized clinical trial; systematic review with meta-analysis

2. Well-designed controlled trial without randomization; prospective comparative cohort trial

3. Case-control studies; retrospective cohort study

4. Case series with or without intervention; cross-sectional study

5. Opinion of respective authorities; case reports

b. Features associated with higher morality - ARDS, Type I respiratory failure, acute cardiac injury, heart failure, hypoxic encephalopathy, sepsis, alkalosis, AKI, DIC, hyperkalaemia, shock and acute liver injury were complications frequently observed in those who died than those recovered ( $n=161)$. Old age, male sex and presence of comorbidities were associated with higher mortality.

c. Seoul National University Hospital, National Medical Centre and Seoul Medical Centre Incheon Medical Center, Incheon; Seoul National University Bundang Hospital and Armed Forces Capital Hospital, Seongnam; Myongji Hospital, Goyang; Gyeonggi Provincial Medical Center Ansung Hospital, Anseong; Wonkwang University Hospital, Iksan; Chonnam National University Hospital and Chosun University Hospital, Gwangju, Republic of Korea

Table 2. The frequencies of symptoms in each study and prevalence across the studies for each symptom. 


\begin{tabular}{|c|c|c|c|c|c|c|c|c|c|c|}
\hline \multirow{6}{*}{ Clinical feature } & \multirow{6}{*}{$\begin{array}{l}\text { Prevalence } \\
\text { From } \\
\text { Meta- } \\
\text { analysis }\end{array}$} & \multirow{5}{*}{$\begin{array}{l}\text { CHINA } \\
\text { Guan W } \\
\text { Number(\%) }\end{array}$} & \multirow{5}{*}{$\begin{array}{l}\text { CHINA } \\
\text { Chen T } \\
\text { Number(\%) }\end{array}$} & \multirow{5}{*}{$\begin{array}{l}\text { CHINA } \\
\text { Chen J } \\
\text { Number(\%) }\end{array}$} & \multirow{5}{*}{$\begin{array}{l}\text { CHINA } \\
\text { Zhou F } \\
\text { Number(\%) }\end{array}$} & \multirow{5}{*}{$\begin{array}{l}\text { CHINA } \\
\text { Zheng F } \\
\text { Number(\%) }\end{array}$} & \multirow{5}{*}{$\begin{array}{l}\text { CHINA } \\
\text { Wang D } \\
\text { Number(\%) }\end{array}$} & \multirow{5}{*}{$\begin{array}{l}\text { CHINA } \\
\text { Kui L } \\
\text { Number(\%) }\end{array}$} & \multirow{5}{*}{$\begin{array}{l}\text { CHINA } \\
\text { Chen N } \\
\text { Number(\%) }\end{array}$} & \multirow{5}{*}{$\begin{array}{l}\mathrm{CH} \\
\mathrm{Zh} \\
\mathrm{Nu}\end{array}$} \\
\hline & & & & & & & & & & \\
\hline & & & & & & & & & & \\
\hline & & & & & & & & & & \\
\hline & & & & & & & & & & \\
\hline & & $\mathrm{N}=1099$ & $N=274$ & $n=249$ & $\mathrm{~N}=191$ & $N=161$ & $N=138$ & $N=137$ & $\mathrm{~N}=99$ & $N=$ \\
\hline \multirow[t]{2}{*}{ Fever } & 79.56 & $975(88.7)$ & 249(91) & $217(87) .1$ & $180(94)$ & $122(75.8)$ & 136(98.6) & $112(81.8)$ & $82(83)$ & 75 \\
\hline & $\begin{array}{l}(72.17- \\
86.09)\end{array}$ & & & & & & & & & \\
\hline \multirow[t]{2}{*}{ Cough } & 56.66 & $745(67.8)$ & $185(68)$ & $91(36.5)$ & $151(79)$ & 101(62.7) & $82(59.4)$ & $66(48.2)$ & $81(82)$ & 59 \\
\hline & $\begin{array}{l}(48.59- \\
64.55)\end{array}$ & & & & & & & & & \\
\hline \multirow{2}{*}{$\begin{array}{l}\text { Sputum } \\
\text { production }\end{array}$} & 22.43 & $370(33.70$ & $83(30)$ & & $44(23)$ & & $37(26.8)$ & $6(4.4)$ & & \\
\hline & $\begin{array}{l}(13.8- \\
32.41)\end{array}$ & & & & & & & & & \\
\hline \multirow{2}{*}{$\begin{array}{l}\text { Shortness of } \\
\text { breath }\end{array}$} & 18.24 & 205(18.7) & $120(44)$ & 19(7.6) & & $23(14.3)$ & $43(31.2)$ & $26(19 \%)$ & $31(31)$ & \\
\hline & $\begin{array}{l}(12.07- \\
25.32)\end{array}$ & & & & & & & & & \\
\hline \multirow[t]{2}{*}{ Tachypnoea } & 22.61 & & & & & & & & & 11 \\
\hline & $\begin{array}{l}(3.94- \\
49.86)\end{array}$ & & & & & & & & & \\
\hline \multirow[t]{2}{*}{ Haemoptysis } & 2.31 & $10(0.9)$ & $7(3)$ & & & & & $7(5.1 \%)$ & & \\
\hline & $\begin{array}{l}(0.48- \\
5.28)\end{array}$ & & & & & & & & & \\
\hline Sneezing & $\begin{array}{l}40(30.07 \text { - } \\
50.35)\end{array}$ & & & & & & & & & \\
\hline \multirow[t]{2}{*}{ Tonsil swelling } & 2.09 & $23(2.1)$ & & & & & & & & \\
\hline & $\begin{array}{l}(1.32- \\
3.03)\end{array}$ & & & & & & & & & \\
\hline \multirow{2}{*}{$\begin{array}{l}\text { Sore throat/ } \\
\text { Pharyngalgia }\end{array}$} & 14.19 & 153(13.9) & $12(4)$ & $16(6.4)$ & & & $24(17.4)$ & & $5(5)$ & 19 \\
\hline & $\begin{array}{l}(8.7- \\
20.68)\end{array}$ & & & & & & & & & \\
\hline $\begin{array}{l}\text { Rhinorrhoea } \\
\text { and/or nasal } \\
\text { congestion }\end{array}$ & $\begin{array}{l}6.86(2.91 \\
-12.09)\end{array}$ & $53(4.8)$ & & $17(6.8)$ & & & & & $4(4)$ & \\
\hline \multirow[t]{2}{*}{ Cold } & 55.56 & & & & & & & & & \\
\hline & $\begin{array}{l}(45.16- \\
65.72)\end{array}$ & & & & & & & & & \\
\hline \multirow[t]{2}{*}{ Chest tightness } & 18.09 & & 103(38) & & & & & & 2(2) & 21 \\
\hline & $\begin{array}{l}(1.66- \\
45.64)\end{array}$ & & & & & & & & & \\
\hline \multirow[t]{2}{*}{ palpitation } & 7.3 & & & & & & & $10(7.3 \%)$ & & \\
\hline & $\begin{array}{l}(3.46- \\
12.33)\end{array}$ & & & & & & & & & \\
\hline \multirow[t]{2}{*}{ Chills } & 16.23 & $126(11.5)$ & & & & & & & & 21 \\
\hline & $\begin{array}{l}(6.49- \\
29.18)\end{array}$ & & & & & & & & & \\
\hline \multirow{2}{*}{$\begin{array}{l}\text { Fatigue ( } \\
\text { Tiredness) }\end{array}$} & 37.1 & $419(38.1)$ & $137(50)$ & $39(15.7)$ & $44(23)$ & 64(39.8) & $96(69.6)$ & $44(32.1)$ & & 35 \\
\hline & $\begin{array}{l}(27.75- \\
46.96)\end{array}$ & & & & & & & & & \\
\hline \multirow[t]{2}{*}{ Dizziness } & 8.1 & & $21(8)$ & $28(11.2)$ & & & $13(9.4)$ & & & $3(\approx$ \\
\hline & $\begin{array}{l}(5.33- \\
11.35)\end{array}$ & & & & & & & & & \\
\hline
\end{tabular}




\begin{tabular}{|c|c|c|c|c|c|c|c|c|c|c|}
\hline \multirow[t]{2}{*}{ Headache } & 15.58 & \multirow[t]{2}{*}{$150(13.6)$} & \multirow[t]{2}{*}{$31(11)$} & \multicolumn{2}{|l|}{ 28(11.2) } & \multirow[t]{2}{*}{$12(7.5)$} & \multirow[t]{2}{*}{$9(6.5)$} & \multirow[t]{2}{*}{$13(9.5 \%)$} & \multicolumn{2}{|l|}{$8(8)$} \\
\hline & $\begin{array}{l}(9.21- \\
23.16)\end{array}$ & & & & & & & & & \\
\hline \multirow{2}{*}{$\begin{array}{l}\text { Altered } \\
\text { consciousness }\end{array}$} & 5.94 & & & & & & & & $9(9)$ & $3(\approx$ \\
\hline & $\begin{array}{l}(1.49- \\
12.73)\end{array}$ & & & & & & & & & \\
\hline Abdominal pain & $\begin{array}{l}3.66(1.39 \\
-6.76)\end{array}$ & & $19(7)$ & & & & $3(2.2)$ & & & $2(2$ \\
\hline \multirow[t]{2}{*}{ Diarrhoea } & 8.26 & $42(3.8)$ & $77(28)$ & $8(3.2)$ & $9(5)$ & 17(10.6) & 14(10.1) & $11(8.0 \%)$ & $2(2)$ & 14 \\
\hline & $\begin{array}{l}(4.36- \\
13.15)\end{array}$ & & & & & & & & & \\
\hline \multirow{2}{*}{$\begin{array}{l}\text { Anorexia/ } \\
\text { Inappetence }\end{array}$} & 17.62 & - & $66(24)$ & $8(3.2)$ & & & $55(39.9)$ & & & 11 \\
\hline & $\begin{array}{l}(4.42- \\
36.82)\end{array}$ & & & & & & & & & \\
\hline \multirow{5}{*}{$\begin{array}{l}\text { Conjunctival } \\
\text { congestion/ } \\
\text { injection }\end{array}$} & 0.82 & $9(0.8)$ & & & & & & & & \\
\hline & $\begin{array}{l}(0.36- \\
1.45)\end{array}$ & & & & & & & & & \\
\hline & & CHINA & CHINA & CHINA & CHINA & CHINA & CHINA & CHINA & CHINA & $\mathrm{CH}$ \\
\hline & & Numbor(\%) & Chen T & Chen J & Zhou F & Zheng F & Wang D & Kui L & Chen N & $\mathrm{Zh}$ \\
\hline & & (19) & Number(\%) & Number(\%) & Number(\%) & Number(\%) & Number(\%) & Number(\%) & Number(\%) & $\mathrm{Nu}$ \\
\hline \multirow[t]{3}{*}{ Clinical feature } & Prevalence & $\mathrm{N}=1099$ & $\mathrm{~N}=274$ & $\mathrm{n}=\mathbf{2 4 9}$ & $\mathrm{N}=191$ & $\mathrm{~N}=161$ & $\mathrm{~N}=138$ & $\mathrm{~N}=137$ & $N=99$ & $\mathrm{~N}=$ \\
\hline & From & & & & & & & & & \\
\hline & $\begin{array}{l}\text { Meta- } \\
\text { analysis }\end{array}$ & & & & & & & & & \\
\hline \multirow[t]{2}{*}{ Rash } & 0.18 & $2(0.2)$ & & & & & & & & \\
\hline & $(0-0.55)$ & & & & & & & & & \\
\hline \multirow[t]{2}{*}{ Lymphadenopathy } & 0.18 & $2(0.2)$ & & & & & & & & \\
\hline & $(0-0.55)$ & & & & & & & & & \\
\hline \multirow[t]{2}{*}{ Nausea } & 6.58 & $55(5.0)$ & $24(9)$ & & $7(4)$ & $6(3.7)$ & 14(10.1) & & $1(1)$ & 11 \\
\hline & $\begin{array}{l}(4.09- \\
9.56)\end{array}$ & & & & & & & & & \\
\hline \multirow[t]{2}{*}{ Vomiting } & 4.95 & $55(5.0)$ & $16(6)$ & & $7(4)$ & & $5(3.6)$ & & $1(1)$ & \\
\hline & $\begin{array}{l}(2.86- \\
7.54)\end{array}$ & & & & & & & & & \\
\hline \multirow[t]{2}{*}{ Myalgia } & 19.37 & $164(14.9)$ & $60(22)$ & & $29(15)$ & 18(11.2) & $48(34.8)$ & $44(32.1)$ & $11(11)$ & 15 \\
\hline & $\begin{array}{l}(14.47- \\
24.77)\end{array}$ & & & & & & & & & \\
\hline \multirow{2}{*}{$\begin{array}{l}\text { Arthralgia/ } \\
\text { Arthrodynia }\end{array}$} & 26.24 & 164(14.9) & & & & & & & & $8(\varepsilon$ \\
\hline & $\begin{array}{l}(4.89- \\
56.39)\end{array}$ & & & & & & & & & \\
\hline \multirow[t]{2}{*}{ Anosmia } & 46.84 & & & & & & & & & \\
\hline & $\begin{array}{l}(35.89- \\
57.93)\end{array}$ & & & & & & & & & \\
\hline \multirow[t]{2}{*}{ Malaise } & 63.33 & & & & & & & & & \\
\hline & $\begin{array}{l}(53.08- \\
73.03)\end{array}$ & & & & & & & & & \\
\hline \multirow[t]{2}{*}{ weakness } & 11.47 & & & & & & & & & \\
\hline & $\begin{array}{l}(0.41- \\
31.75)\end{array}$ & & & & & & & & & \\
\hline Asymptomatic & 2.71 & & & $7(2,8)$ & & & & & & \\
\hline
\end{tabular}


Table 3 - Comparison covid-19 symptoms identified with that of major publications

\begin{tabular}{|c|c|c|c|c|c|c|c|}
\hline \multirow[t]{3}{*}{ Clinical feature } & Prevalence (\%) & $\mathrm{WHO}^{1}$ & $\mathrm{NHS}^{2}$ & $\mathrm{CDC}^{3}$ & Chinese $^{4}$ CDC & Institut Pasteur ${ }^{5}$ & \multirow[t]{3}{*}{ Mayo Clinics $^{6}$} \\
\hline & From & & & & & & \\
\hline & Meta-analysis & & & & & & \\
\hline Fever & 79.6 & $\checkmark$ & $\checkmark$ & $\checkmark$ & $\checkmark$ & $\checkmark$ & $\checkmark$ \\
\hline Cough & 56.7 & $\checkmark$ & $\checkmark$ & $\checkmark$ & $\checkmark$ & $\checkmark$ & $\checkmark$ \\
\hline Sputum production & 22.4 & & & & & & \\
\hline Shortness of breath & 18.2 & & & & & & \\
\hline Tachypnoea & 22.6 & & & & & & \\
\hline Haemoptysis & 2.3 & & & & & & \\
\hline Sneezing & 40.0 & & & & & & \\
\hline Tonsil swelling & 2.1 & & & & & & \\
\hline Sore throat/ Pharyngalgia & 14.2 & $\checkmark$ & & $\checkmark$ & $\checkmark$ & & $\checkmark$ \\
\hline Rhinorrhoea and/or nasal congestion & 6.9 & $\checkmark$ & & $\checkmark$ & $\checkmark$ & & \\
\hline Cold & 55.6 & $\checkmark$ & & & & & \\
\hline Chest tightness & 18.1 & & & & & & \\
\hline palpitation & 7.3 & & & & & & \\
\hline Chills & 16.2 & & & & & & \\
\hline Fatigue ( Tiredness) & 37.1 & $\checkmark$ & & $\checkmark$ & $\checkmark$ & & $\checkmark$ \\
\hline Dizziness & 8.1 & & & & & & \\
\hline Headache & 15.6 & $\checkmark$ & & $\checkmark$ & & $\checkmark$ & $\checkmark$ \\
\hline Altered consciousness & 5.9 & & & & & & \\
\hline Abdominal pain & 3.7 & & & & & & \\
\hline Diarrhoea & 8.3 & $\checkmark$ & & $\checkmark$ & $\checkmark$ & & $\checkmark$ \\
\hline Anorexia/ Inappetence & 17.6 & & & & & & \\
\hline Conjunctival congestion/ injection & 0.9 & $\checkmark$ & & & & & \\
\hline Rash & 0.2 & & & & & & $\checkmark$ \\
\hline Lymphadenopathy & 0.2 & & & & & & \\
\hline Nausea & 6.6 & & & $\checkmark$ & & & $\checkmark$ \\
\hline Vomiting & 4.0 & & & $\checkmark$ & & & $\checkmark$ \\
\hline Myalgia & 19.4 & $\checkmark$ & & $\checkmark$ & $\checkmark$ & $\checkmark$ & $\checkmark$ \\
\hline Arthralgia/ Arthrodynia & 26.2 & & & & & & \\
\hline Anosmia & 46.8 & $\checkmark$ & $\checkmark$ & $\checkmark$ & & $\checkmark$ & $\checkmark$ \\
\hline Malaise & 63.3 & $\checkmark$ & & & & & \\
\hline weakness & 11.8 & & & & & & \\
\hline Asymptomatic & 2.7 & & & & & & \\
\hline
\end{tabular}


Figures

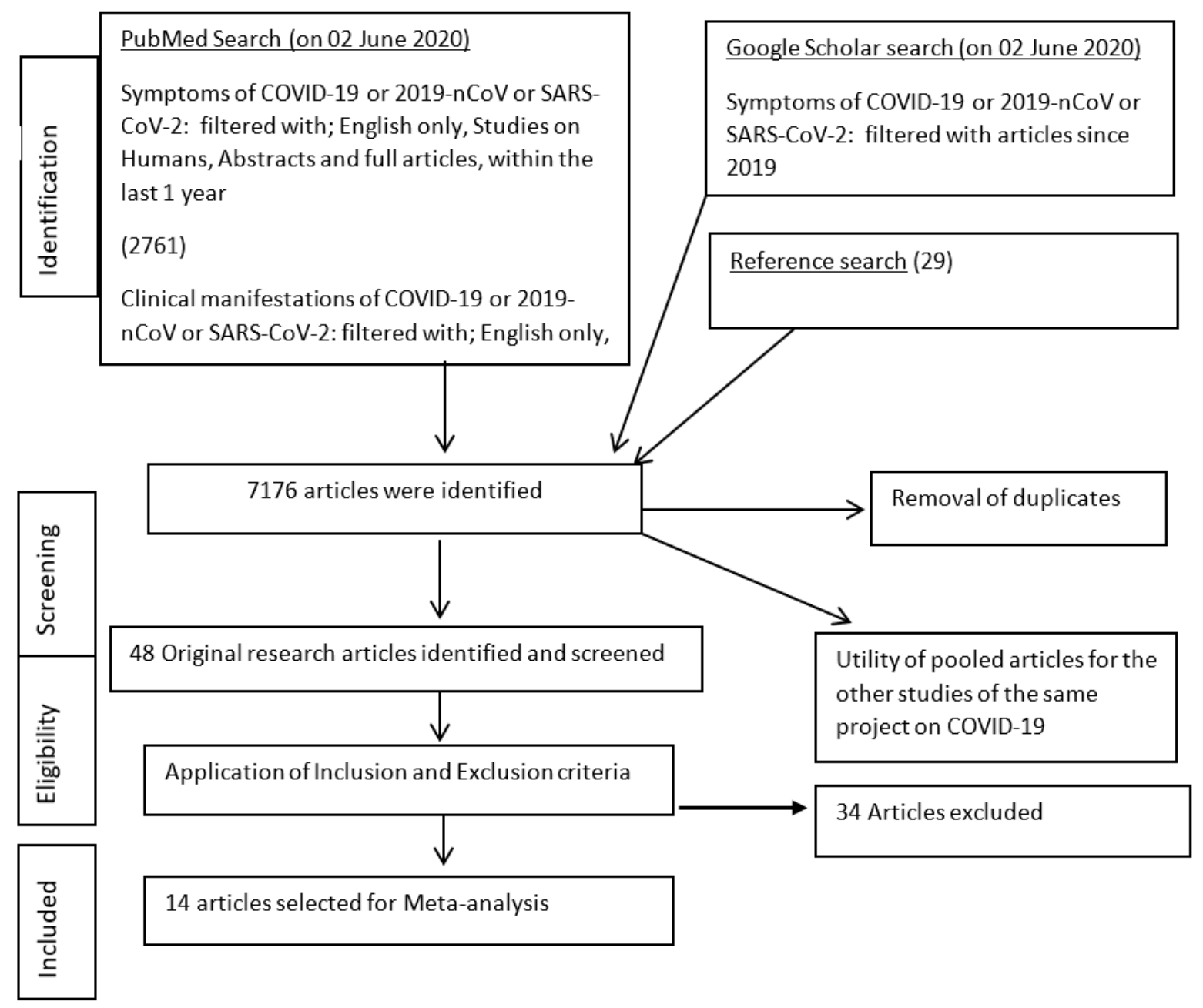

Figure 1

The flow chart that shows the process of identification, selection and inclusion of articles into the meta-analysis 


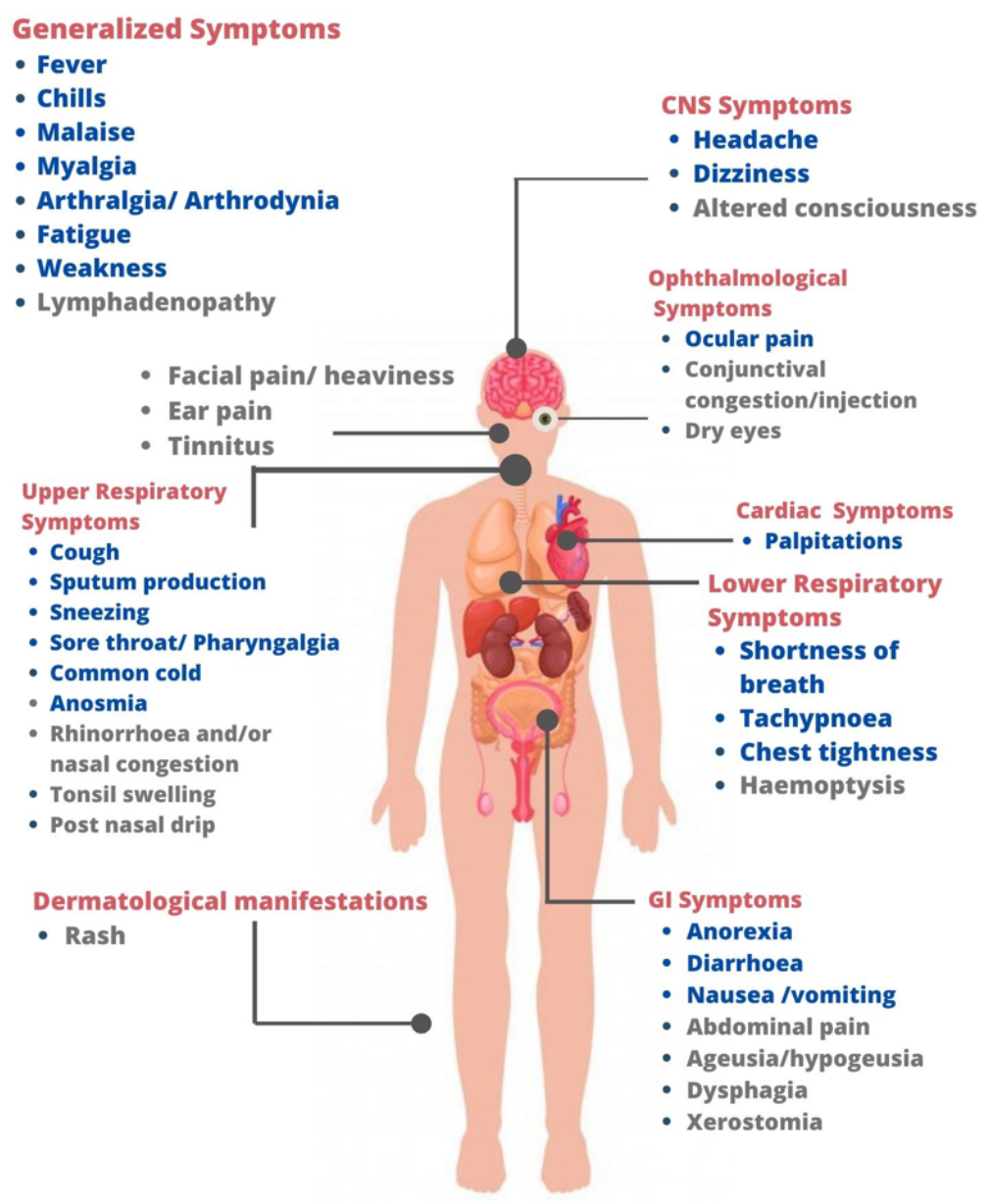

Figure 2

Symptoms of COVID-19. Generalized and organ specific symptoms are shown. Total of 39 symptoms are shown. Common symptoms are in blue. Uncommon once are in gray.

\section{Supplementary Files}

This is a list of supplementary files associated with this preprint. Click to download.

- PRISMA2009checklist.doc

- Figure1.ResultsofMetaanalysis.docx 